The method of providing attractive syllabi is by no means widespread amongst organizers of lecture courses. The syllabus for the 1958 Commonwealth Fund Lectures, therefore, has much to commend it. Certainly, those who live far away from London will regard it with onvy, for it outlines a course which is sufficiently small in chronological compass to be manageable and yet at the same time examines matters of sufficient importance to ensure that the auditors will take away not merely details of the passing hour but also something of the enduring themes of American government and politics.

\title{
B.A.A.S. GRANTS FOR RESEARCH IN AMERICAN STUDIES
}

The Rockefeller Foundation has generously made available a sum of money to the Association to encourage research in this country in American history, literature, and institutions. The Association proposes to make the following awards for the academic year 1958-59:-

(1) Two grants, each of $\$ 1,000$, for research on Azerican studies within the United Kingdom.

(2) Two grants, e ach of $\$ 3,000$, to graduate students, to enable them to spend one academic year on research in the U.S.

(3) Twp grants, each of $\$ 6,000$, to established scholars to enable them to spend one academic year on research in the U.S.

These awards will be made in April 1958 by a Committee of Award, which is empowered to vary the amounts and number of the awards in the second and third categories to permit shorter visits if necessary.

Applications (eight copies) for any of these awards should be made by letter, stating qualifications, academic position and publications (if any), and giving precise indications of the research project in American studies. No testimonials should be sent but names should be given of two academic referees to whom reference may be made. Applications should reach the undersigned by Warch 26th, 1958:- Professor Esmond Wright, (kcting Hon. Sec, of the B.A.A.S.), Department of History, The University, Glasgow, W. 2.

\section{B.A.A.S: THIRD ANNUAL CONFERENCE}

Although members are to receive individual notification of the Conference, we reproduce below part of the Acting Secretary's circular fer the onvenience of any nembers who, through some postal mishap, may not have seen this announcement.

The Annual General Meeting of the Association will be held from March 26th to March 29th, 1958, at the University College of Wales at Aberystwyth. Accoinmodation will be provided in Pantycelyn, the College's new hall of residence overlooking town and sea from the slopes of the hill alongside the National Library of Wales (single study-bedrooms and all mod. cons., with a few double bedrooms for married couples). Within five minutes driving (any direction except West) is the finest country in Wales; five minutes by Sputnik westward lies Anerica. Members will provide their own vehicles.

Relevant particulars follow:-

ASSEMBLE: Tea, 4 p.m. March 26th; sherry at 6 p.m. LDDRESS: Pantycelyn Hall, Ponglals Road, iborystwyth. Telephone: diberystwyth 642. MEAL-TIMES: Breakfast 8.15; Lunch 1.00 p.m.; Tea 4 p.m.; Dinner 7.00 p.m. SPEAKERS: Carlos Baker (American Literature); Wallace Davies (Gmerican History); L. F. Freund (itmerican Government); Possibly: C. Wright Mills (Sociology); S. K. Bailey (American Politics). Other speakers and discussion-groups may also be arranged.

COST: From tea Wednesday (March 26th) to after breakfast Saturday (March 29th), £3. 7s. 6d.

CONFERENCE SECRETARY: LIan Conway, Lecturer in American History at Aberystwyth, has nobly undertaken the duties of Conference Secretary. 
Members who wish to attend all or part of the Conference should write to the Conference Secretary not later thion March 14th. If possible, estimated time of arrival in $\Lambda$ berystwyth should be given. The Conference Secretary's address is:- Alan Conway, "Florida", Penglais Road, Aberystwyth. Telephone: Aberystwyth 7765 .

\section{NEWWS OF MEMBERS}

\section{old Members}

Mr. H. I. Beales (Director of the Survey of Sources for American Studies in the United Kingdom). We are pleased to hear that Mr. Beales is now convalescing from his recent illness and hope that he will soon be restored to good health.

Mr. Marcus Cunliffe at the Center for Advanced Study in the Behavioral Sciences, Stanford, California, is completing his contribution to the "History of American Civilization" series of Chicago University Press under the general editorship of Professor Daniel Boorstin: a study of American history during the period 1789-1837.

Mr. Peter d'A Jones. The note on Mir. d'A Jones which appeared in Bulletin, No. 4, p. 25, should be amended to read:- 1. M.A. (Manchester): temporary Assistant Lecturer in American History and Institutions, University of Manchester. 2. 62, Daisy Bank Road, Victoria Park, Manchester, 14. 3. No ontry. 4. An Economic History of the United States (Routledge and Kegan Paul, London, 1956). 5. Interested in Anerican economic, social and intellectual history.

Mr. Peter Marshall (University of Bristol). We are pleased to note that, in his researches into the influence of Edward Bellany in Great Britain, Mr. Marshall has discovered that the eighty-eight year old editor of the British Bellaryite periodical lives only five miles away from him.

Mr. Herbert Nicholas (New College, Oxford) spent the autumn term in the United States - largely, we understand, at the United Nations.

Mr. George Shepperson's study (with Thomas Price, Lecturer in African Studies, University of Glasgow), Independent African. John Chilembwe and the Origins, Setting and Significance of the Nvasaland Native Rising of 1915 is to be published by Edinburgh University Press in the spring of 1958. The work explores some neglected byways in American Negro history through its examination of John Chilembwe, leader of the Nyasaland Native Rising of 1915, who was educated in a Negro theological serninary in Virginia and was strongly influenced by American Negroes at a time of great racial tension in the United States.

Me. Desmond Tarrant is still at the Department of fmerican Civilization in the University of Pennsylvania where he id dolng the work of Visiting Professor. He pronises the Bulletin an article on James Branch Gabell, the subject of his proposed book.

\section{Publications}

W. R. Brock, The Effect of the Loss of the American Colonies on English Policy (London: "Aids for Teachers" series of the Historical Association, 1957,2s.).

D. W. Brogan, "The United States. Civilian and military power" in Soldiers and Governments. Nine Studies in Civil-Military Relations, edited by Michael Howard (London: Eyre and Spottiswoode. 1957. 21s.). Originally given as a Third Programme broadcast.

D. W. Brogan, "The End of Illusion", The Yale Review (New Haven, Connecticut) XLVII, December 1957, 2, pp. 162-174. An important porsonal statement on the United States in the Sputnik Age.

Charlotte Erickson, Anorican Industry and the European Immigrant. 1850-1885 (Cambridge, Massachusetts: Harvard University Press. Juondon: Oxford University Press. 1957. \$4/.75). An intensely documented study of the reactions of Anerican capital and labour to the contract labour laws in the Unitod States. 